\title{
世界湖沼会議にNGO コーディネーターとして参加して
}

\author{
井手慎 司 \\ (滋賀県立大学・本誌編集委員)
}

北欧の環境首都コペンハーダンにおいて，去る 5 月17日から21日にかけて, 第 8 回世界湖沼会議が開 催された。同会議は，湖沼やダム湖の環境保全につ いて，研究者や行政官，市民が一堂に会して話し合 うことを目的としており，1984年に滋賀県大津で第 1 回目が開かれてから, 今回で 8 回目となる. 会議 には世界60ヶ国から487名が参加し,うち NGO 登録 者数は70名, 日本からの参加者は124名に上った.

この大会における筆者の役割は，会議のホスト， コペンハーゲン市に協力して非政府機関や市民団体 （NGO）向けプログラムを成功させることであっ た。幸い, 同市環境保護局への訪問や, 個別セッシ ヨン, ワークショップ, 専用のエクスカーションな どで構成されたプログラムは好評を博したようだ。 同時に，このコーディネーター役を勤めたことで， 現地のさまざまな環境 NGO 活動について触れる機 会に恵まれた。以下，そのことを中心に報告したい.

\section{〈デンマーク自然保護協会〉}

今回もっとも印象深かったのがデンマーク自然保 護協会 (以下, DN と略す)だ。同協会の設立は1911 年と古く，その会員数は国内だけで 26 万人に上る. 人口が約 525 万人の小さ国だけに,この数字は全人 口の約 $5 \%, 10$ 軒の家庭に 1 軒が加入しているとい う「お化け」団体である。現在の活動は，自然保護， 環境保護, 国際協力など多岐にわたっており, 専従 の職員数はわずか 40 名, 会員からの会費 (年間約 4,000円）のみでその活動費の 4 分の 3 を賄ってい る.

同協会は自らを「環境の番犬」と呼ぶ (DN のホー ムページ URL:http://www.dn.dk/を哯いてみる と, 地球を抱えたマスコットのイヌが登場する)。ま た，自分たちの役割は，市民と行政とを結ぶ「ダイ アローグ (対話) 役」であるとも定義している. 組 織としては, National Steering Committee と14の
Consultative Council, その下の220の Local Committee という 3 層から成っており, 各層が国, 郡, 市町村レベルの行政組織にそれぞれ対応している. このこともまた, 行政と市民との対話を促進するた めの仕組みだという.

同協会が持つもつとも大きな武器は, 法的に認め られた次の 3 つの権利だ：1) 自然保護地域を提案す る，2)開発の計画段階から参画する，3）アピール権 をもつ. 特にDN は最後の「アピール権」を重視し ている（同国環境保護法第99条が DN に保証してい るこの権利は, DN ばかりではなく, 関係住民やその 他の環境保護団体, 労㗢組合にも認められている. デンマークが環境政策の柱としている「パートナー シップ」を具現化した 1 例なのだろう.コペンハー ゲン市環境保護局からも，このアピール制度を重視 するという発言を聞いている).

デンマークではすべての開発行為が認可の対象と なっており (許認可権は, 開発行為の規模によって 市町村か郡に分かれる), 行政へ提出されたこれら認 可申請は同時に，そのコピーがすべて DN に送られ る仕組みとなっている(年間このような申請が7,000 件に上る)。DN はこれらの申請を独自に審査してお り，申請に対する行政の決定に不服がある場合，そ の旨を国のアピールボードへ上告する権利をもつ —これが「アピール権」だ。不服の申し立てを受 けたアピールボードは, 当該の案件を再審議して, 政府としての最終決定をくだす．DN から提出され る年間150件のアピールの内, その半数が DN 側の 勝訴に終わるという。ただし，アピール権の効用は むしろその「抑止力」にある.アピール権の存在に よって，行政はつ亦にその存在を意識しながら判断 を下さなければならないからである。

\section{〈環境先進国デンマーク〉}

今回の会議では DN 以外にも, アレー湖協会や 


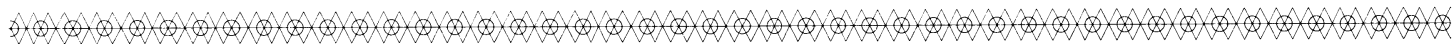

Friends of Kolindsunds (Kolindsunds という湖の 復元をめざす団体), Saving Village Pond(ため池の 保護を訴える団体)など，同国における複数の環境 NGO の活動について情報を得ることができた.

結果だけを言えば，日本からの NGO 参加者の多 くは，あまりの違いにショックを受けたのではない だろうか. 特に日本でいう「実践活動」と呼べるよ うな活動がほとんど見当たらない. 啓発（キャンペ ーン）活動や出版活動，行政の意志決定プロセスへ の参画など，広い意味で「情報活動」とでもいうべ き活動がデンマークにおける NGO 活動の中心だっ た。

誤解を恐れず言ってしまえば... 污くなったドブ 川を前にして,「さあ,みんなできれいにしましょう」 とご近所に呼びかけ，自らドブ浚いをするのが日本 流 NGO の活動様式であるならば,「污いからきれい にしてもらいましょう」と行政に働きかけ，それを 達成するのがデンマーク流のやり方だった.

また上述した DN は，自然保護だけを盲目的に訴 える団体ではない，私が聞いた事例では，ある孤島 の自然保護計画があまりにも過剩保護であるとし て, DN がその計画の承認にクレームをつけ, 認めさ せなかったケースすらあったという。

つまり，ぞうも土台となるモノの考方方や，社会 の成熟度が違いすぎているようである，われわれ日 本人からの質問に対して，なぜそんなことが聞かれ るのか，質問の意味すら理解できない，困ったとい う顔をする現地の人に何人も出会った。そんな時は, はずかしいことを聞いてしまったと，こちらのほう が赤面してしまう.「自然や環境を守ることは当然の こと.なぜそんなことを不思議がるのか. 問題は, その目的を達成するための方法論でしょう」と. 彼 らは当然のことを当然のように，サラリとやってし まう。

同行していた環境市民滋賀の堤氏によれば，まだ ドイツのほうが親近感を覚えるという。確かに環境 の分野に扔いて，ドイツは日本よりいくぶん進んで いるようだが，炭素税をめぐる連立政権内での緑の 党と他党とのゴタゴタのように，よたよた進んでい る様がいかにも人間臭い. 端から見ていてよく理解 できるぶんホッとしますと.

われわれが環境先進国という場合, 通常, 北欧諸
国（デンマークを含む）にオランダを加えて話をす る、しかしなぜ，それらの国々において，国民の環 境意識が高いのか. なにがそれら環境先進国を他の 国々と隔てているのか？ 現地の活動家と話してい て, 部分的ではあるが，わかったような気がする. あるDN メンバーが次のように答えてくれた— “Because we are BAD countries!”ここでの “BAD”とは，われわれの国（デンマークやオラン ダ)は自然や国土に恵まれていない，その意味で「悪 い」国だ，という意味である。

よく知られているように，オランダはオランダ人 （干拓）によって造りだされた.デンマークもデン マーク人が, 不毛のユトランド半島を必死の努力に よって開墾し, 肥沃な国土へと改変していったこと で造りだされた国だ。過酷な自然と戦いながら，国 土を切り開いていったという点では他の北欧諸国も 同様だろう。つまり，その歴史がかれらに自然や環 境の大切さを教えるのではないか. 自然や環境は決 して神から与えられたモノではない，自分たちの手 でつくりだしたモノ, 守っていかなければならない モノだと（逆に，同じ理由によって 80 年代に入るま では, 自然は人々の思うがままに改変されていった。 デンマークに扔ける現在の自然や環境重視の考え方 には当時に対する深い反省があるという．行政に対 する発言権が DN に与えられたのも 82 年になって からのことである).もちろんそれ以外にも, 国民が 物心ともに豊かである, 知的レベルが高いこともあ るだろうが... ひょっとすると，われわれ日本人は 自然に恵まれすぎているのかもしれない.

\section{〈次回の湖沼会議にむけて〉}

次回の湖沼会議は 2001 年, 再び大津で開かれる. コペンハーゲンの閉会式で国松滋賀県知事が誘致を 発表したのだ。すでに滋賀県の環境 NGOグループ は2001年にむけて活動を開始している．紙面の関係 で簡単にしか述べられないが, 次の湖沼会議は, 滋 賀県の NGO グループにとって，その力量が問われ る重要な会議となるだろう。それを乗り切るために は活動のプロ化しかない, と私は考えている，しか し, 活動家たちの間に, プロ化にたいする抵抗感は 根強い.ただ，その胎動はすでに始まっており，も はや止めようのない潮流であると私は感じている. 